This is a draft chapter. The final version is available in Deplano, Rossana and Tsagourias, Nicholas, (eds.), Handbook of Research Methods in International Law. Cheltenham: Elgar, pp. 458-473 published in 2021

http://dx.doi.org/10.4337/9781788972369.00037

The material cannot be used for any other purpose without further permission of the publisher, and is for private use only Accepted version downloaded from SOAS Research Online: http://eprints.soas.ac.uk/34215

\title{
Feminist Methodologies
}

Gina Heathcote and Paola Zichi

\section{Plural Feminisms}

Feminist methodologies within international law require a renewed effort to address intersectional subjectivity, postcolonial knowledges and international legal histories. In this vein, this chapter explores the concept of plural feminisms as means to develop these intersectional, postcolonial and history-orientated feminist methodologies. We regard plural feminisms as a term that encompasses the understanding and development of multiple feminist accounts and which attends to pluralism in the sense of understanding law itself as a plural enterprise. Plural feminisms and legal pluralisms thus incorporate and expand a feminist methodology that engages gender theories outside of the mainstream feminist traditions within international law, are attentive to plural subjectivities, and which acknowledge gender's co-optation into the histories of empire.

While feminist approaches to international law are often identified as commencing with the work of Charlesworth, Chinkin and Wright in 1991, we use this chapter to identify the longer histories of transnational feminist engagement. ${ }^{1}$ As such, we place the trajectory of subsequent scholarship and gender law reform in nexus with the work of human rights scholars and activists who had framed and pioneered work within the United Nations, ${ }^{2}$ and the long history of peace activists that worked through international organisations, such as Women's International Legal for Peace and Freedom (WILPF), ${ }^{3}$ to build transnational and regional feminist dialogues. Our aim is thus to knit in increased spaces for recognition of the cross-jurisdictional dialogues of feminist legal theorists, whose work influenced much of the early engagements with international law, while exercising a consciousness of the role of gender law reform as a tool of colonialism and as standard of civilisation seemingly exportable from the global north. ${ }^{4}$ We mark

\footnotetext{
${ }^{1}$ Hilary Charlesworth, Christine Chinkin, and Shelley Wright, 'Feminist Approaches to International Law' (1991) 85(4) American Journal of International Law 613

${ }^{2}$ Rebecca Cook (ed), Human Rights of Women: National and International Approaches (University of Pennsylvania Press, 1994)

${ }^{3}$ Women's International League for Peace and Freedom, Generations of Courage (WILPF, 2009) available online: www.wilpfus.org/sites/default/files/docs/Generations $\% 20$ of $\% 20$ Courage_optimized-med.pdf (accessed August 2020)

${ }^{4}$ Ratna Kapur, Erotic Justice: Law and the New Politics of Postcolonialism (Glasshouse Press 2005)
} 
and celebrate the tremendous influence of Charlesworth, Chinkin and Wright, in 1991 and well beyond, ${ }^{5}$ in shaping and making the field, while taking as our springboard Charlesworth et al's own considerable investment in much wider networks of feminist knowledge production both prior and beyond the pivotal scholarship of the early 1990s.

In the following section we address the current state of feminisms within international law and institutions. We focus on how feminist successes have appeared through the development and building of key scholarly interventions from the early 1990s. The law reform that resulted, we argue, has increasingly become subject to fragmentation within international institutions and constrained by larger patterns that move toward the reliance on expertise and indicators within international legal institutions. ${ }^{6}$ This is followed by an account of how these successes might be championed or celebrated and yet still understood as ultimately constrained by the institutions they operate within. There is a necessity, we argue, to look at the shape of gender law reform and to then examine which feminisms are left out as a means to develop feminist methodologies that are able to reconsider the space and place of gender law reform within international law. As such, in section three we examine contemporary accounts from the work of scholars within international law whose methodologies are attuned to history, alongside gender theories that develop feminist historiographies and engagements with archives to explore the intersectional and postcolonial dimensions via a turn to historiography within feminist approaches to international law. ${ }^{7}$ This is thus plural feminisms: plural in the sense of being diverse and multiple, as well as dynamic and evolving across transnational contexts but also plural in the sense of attentiveness to legal pluralism and plural subjectivities in a manner that is an important pre-step to constructing legal knowledge differently. In section four we commence a brief application of the methodologies identified as a means to tell, and re-tell, feminist histories of peace activism and the role they play in knowledge production: in international law and in the

\footnotetext{
${ }^{5}$ Hilary Charlesworth, Christine Chinkin and Shelley Wright, 'Feminist Approaches to International Law: Reflections from Another Century' in Buss and Manji, International Law; Modern Feminist Approaches (Hart, 2005)

${ }^{6}$ For an alternative reading of the impact of fragmentation, see: Catherine O'Rourke and Aisling Swaine 'CEDAW and the Security Council: Enhancing Women's Rights in Conflict' (2018) 67 International and Comparative Law Quarterly 167

${ }^{7}$ Nadia A. Swaby and Chandra Frank, 'Special Issue of Feminist Review on the Archive' (2020) 125 Feminist Review
} 
transnational. Section five offers a conclusion and summary of the larger contribution of the chapter.

\section{Fragmentation, Expertise and Indicators}

This section acknowledges the rise of feminist approaches within the discipline of international law post-1991. Not only has Charlesworth, Chinkin and Wright's 1991 text, and Charlesworth and Chinkin's subsequent book, inspired considerable scholarship, a key outcome has been transformative feminist lobbying of international institutions that has altered, in particular, the landscape of international human rights law, international criminal law and collective security approaches. ${ }^{8}$ Additional early scholars included Gardam, whose work on international humanitarian law remains unsurpassed in its methodological rigor, ${ }^{9}$ Engle, whose accounts of human rights and groundbreaking interrogations of the risks and limits of feminist engagements with law were pivotal in the later development of governance feminism critiques, ${ }^{10} \mathrm{Knop}$, whose contributions includes engagements with self-determination, transnational law and indigenous rights, ${ }^{11}$ and Otto, whose oeuvre of work spans human rights, LGBT and queer engagements and significant accounts of feminist approaches to collective security and histories of peace activism. ${ }^{12}$ These scholarly accounts, and the many that emerged alongside them, in terms of feminist methodologies are of considerable diversity engaging tensions and identifying the limitations of gender law reform while consistently and consciously challenging international law across its sub-disciplines.

\footnotetext{
${ }^{8}$ Above note 5; Christine Chinkin and Hilary Charlesworth, The Boundaries of International Law: a Feminist Analysis (Manchester University Press, 2000)

${ }^{9}$ Judith Gardam 'Women and the Law of Armed Conflict: why the silence?' (1997) 46 ICLQ 5; Judith Gardam, 'War, Law, Terror, Nothing New for Women' (2010) 32 Australian Feminist Law Journal 61

${ }^{10}$ Karen Engle, 'International Human Rights and Feminism: When Discourses Meet' (1992) 13 Michigan Journal of International Law 317; Karen Engle, 'International Human Rights and Feminisms: Where Discourses Keep Meeting' in Buss, D, and Manji, A, (eds), International Law: Modern Feminist Approaches (Hart 2005), Karen Engle, The Grip of Sexual Violence in Conflict (Stanford, 2020)

${ }^{11}$ Karen Knop, K, 'Re/Statements: Feminism and State Sovereignty in International Law' (1993) 3 Transnational Law and Contemporary Problems 293; Knop, K, 'Here and There: International Law in Domestic Courts' (2000) 32 New York University Journal of International Law and Politics 501; Karen Knop, Diversity and Self-determination in International Law (Cambridge 2002)

${ }^{12}$ Dianne Otto, "A Sign of "Weakness"? Disrupting Gender Certainties in the Implementation of Security Council Resolution 1325' (2006) 13 Michigan Journal of Gender and the Law 113; Dianne Otto, 'The Exile of Inclusion: Reflections on Gender Issues in International Law over the Last Decade' (2009) 10 Melbourne Journal of International Law 11; Dianne Otto (ed), Queering International Law: Possibilities, Alliances, Complicities, Risks (Routledge 2018)
} 
Unlike the diversity of scholarly accounts within feminist legal theories, however, the space of actual law reform on matters related to gender remains remarkably consistent in the forms it takes - drawing in formal equality provisions, protective strategies and special measures that incorporate a combination of US radical, liberal and cultural feminist legal modes. ${ }^{13}$ US radical feminisms, often drawing on the work of MacKinnon, and referred to by Powell as antisubordination feminisms, focus on the impact of sex difference as rendering a hierarchy between men and women that specifically seeks to challenge and prosecute crimes of sexual violence. ${ }^{14}$ Liberal feminist modes encourage the use of law to engender equality, focusing on reforms that facilitate women's inclusion and access to anti-discrimination laws. A cultural feminist approach, at least with in the field of feminist legal theories, prioritises recognition of women as holding experiences and practices as different to men and as a means for alternative ways of knowing and doing in law. We argue that this triad of approaches remain the most influential on gender law reform within international institutions. ${ }^{15}$

Importantly, Kapur's analysis of gender law reform within the domain of international human rights law illustrates how the combined effect of liberal and radical US feminist law reforms constructs a form of 'victim essentialism', deployed into the global south and often actively eradicating the capacity for women on the peripheries to inform the contours of feminist and, or, legal knowledge. ${ }^{16}$ International laws that embrace a gender perspective that collapses into women's perspective undo some of the complexities of understanding gender difference to embed further forms of essentialism, as well as persisting with gender knowledge that is derived from the gender binary and its heteronormative ordering. As such, whether radical, liberal or cultural feminist in its approach mainstream US feminist legal theories remain constrained in their capacity to build an approach to difference, to address the complexity of larger power dynamics or global inequalities within international law and the history of empire.

\footnotetext{
${ }^{13}$ Gina Heathcote, Feminist Dialogues on International Law: successes, tensions, futures (OUP 2019) chapter one ${ }^{14}$ Catherine Powell, 'How Women Could Save the World if Only We Would Let Them: Gender Essentialism and Inclusive Security' (2017) 28 Yale Journal of Law and Feminism 271; see further, Catherine MacKinnon, Are Women Human?: And Other International Dialogues (Harvard University Press, 2006); for a critique see: Prabha Kotiswaran, Dangerous Sex, Invisible Labour: Sex Work and the Law in India (Princeton 2011)

${ }^{15}$ Heathcote, above note 13

${ }^{16}$ Kapur, above note 4
} 
In this chapter, we are interested in feminist methodologies outside of these three dominant legal approaches. Non-mainstream feminist accounts, including US critical race feminisms, postcolonial feminisms and transnational feminisms, remain alienated from institutional reform within international law and its institutions. ${ }^{17}$ This amenability of some and not other feminist legal approaches to gender law reform raises questions about the capacity for re-orientating around plural feminisms, as equally as indicating the limitations of the institutions which these reforms occur within. As such, alongside recognition of the successful take up of radical, liberal and cultural feminist ideas within international legal structures there also needs to be recognition of how gender law reform fragments across the various sub-disciplines of international law in a manner that mirrors the larger fragmentation of international law. ${ }^{18}$ That is, a closer examination of feminist successes demonstrates how the diversification of sites of international law contributes to the fragmentation of gender law reform: across spaces of global governance and a fragmenting of international legal developments from the rich dialogues on gender, sexuality, race, legacies of empire and class that inform wider feminist theories than those that surface in gender law reforms. ${ }^{19}$ To consider feminist methodologies that might shift beyond the constraints imposed by this fragmentation we focus on methodologies derived outside of contemporary gender law reforms, including feminist historiographies and feminist peace activism.

Drawing on Charlesworth's claim 'that feminists have been successful in bringing the language of women's empowerment into international law but less adept at identifying methods to give this language life on the ground', ${ }^{20}$ we argue there is a need to attend to both the methods and message of feminist legal accounts. Within those fragmented spaces we acknowledge the work and consequent restraints on gender experts - both knowing actors often deeply invested in feminist projects and as actors constrained by the institutions that impose the conditions on how

\footnotetext{
${ }^{17}$ See further: Chandra T Mohanty, 'Under Western Eyes: Feminist Scholarship and Colonial Discourse' (1988) 30 Feminist Review 61

${ }^{18}$ Gina Heathcote, 'Fragmented Feminisms: Critical Feminist Thinking in the Post-Millennium Era' in August Reinisch, Mary E Footer, and Christina Binder (eds), International Law and ... Select Proceedings of the European Society of International Law 2014 (Hart 2016) 309

${ }^{19}$ Vasuki Nesiah, V, 'The Ground Beneath Her Feet: 'Third World' Feminisms' (2003) 4(3) Journal of

International Women's Studies 30; Chandra T Mohanty, 'Under Western Eyes: Feminist Scholarship and Colonial Discourse' (1988) 30 Feminist Review 61

${ }^{20}$ Hilary Charlesworth, 'Talking to Ourselves? Feminist Scholarship in International Law' in Sari Kouvo and Zoe Pearson (eds), Feminist Perspectives on Contemporary International Law: Between Resistance and Compliance? (Hart, 2011)
} 
gender law reforms can occur. ${ }^{21}$ In this chapter we consider the methodologies that might inform ways beyond the impasse of what Pearson and Kouvo frame as resistance and compliance. ${ }^{22}$ That is, the loop between critique and reform in feminist engagements with law, which within international institutions have led to constraints on the forms of gender law reform. ${ }^{23}$ The accommodation of specific feminist dialogues on international law into the mainstream of international law has produced, and continues to produce, important outcomes, for the United Nations, for women across communities and for feminist and women's rights advocates. International criminal law and the Security Council women, peace and security initiatives are two key sites where feminist initiatives have had legal implications. ${ }^{24}$ In addition, the longer history of women's human rights initiatives and the incorporation of these, via the Convention on the Elimination of all forms Discrimination against Women (CEDAW) and various World Conferences (on human rights and on women), into international legal dialogues are important histories of diverse sites of feminist action within international spaces; including the development of institutional models on intersectionality.

Tripp and Badri note how African transnational feminists and women's rights activists have 'been influential, particularly in areas such as the political representation of women, in advancing women as economic actors, in adopting strategies to promote peace, and in tackling cultural restraints on women' ${ }^{25}$ Nevertheless despite these gains, and their diverse origins, there is a preoccupation with measures and indicators that often amount to 'counting the women' when mobilised as practice within an institution. In the example of women's political participation, on the one hand, the diverse practices on the African continent have been world-leading, attuned to local gender structures and built varied models for impacting on the over representation of men in political institutions. On the other hand, the international focus has largely been centred on the outputs, a measure of what percentage of women are present within governance rather than either

\footnotetext{
${ }^{21}$ Lucy Ferguson, "This is Our Gender Person": The Messy Business of Working as a Gender Expert in Gender and Development' (2015) 17 International Feminist Journal of Politics 380

${ }^{22}$ Sari Kouvo and Zoe Pearson (eds), Feminist Perspectives on Contemporary International Law: Between Resistance and Compliance? (Hart, 2011)

${ }^{23}$ See further, Heathcote, Feminist Dialogues on International Law, Oxford 2019

${ }^{24}$ Christine Chinkin and Madeleine Rees, 'Commentary on Security Council resolution 2467: Continued State Obligation and Civil Society Obligation on Sexual Violence in Conflict', LSE WPS Working Paper Series, July 2019, available online - http://www.lse.ac.uk/women-peace-security/assets/documents/2019/reports/WPSCommentary-Report-online.pdf

${ }^{25}$ Aili Mari Tripp and Balghis Badri (eds), Women's Activism in Africa (Zed Books 2017) 29
} 
the feminist practices that propelled change or the potential (or limits) of feminist transformation as an outcome.

Accounts of transnational African feminist approaches, the interventions of Middle Eastern feminist actors and networks, the voices of South and central American feminists, and the work of feminists from South Asia across East Asia, South East Asia and to the Pacific, remain fairly muted within feminist accounts of international law. The imagined construction of this transnational feminist work as outside of the discipline of international law contributes to the construction of feminist 'Others' pushed to the peripheries of feminist dialogues on international law. The presence and influence of transnational feminist voices in the history of international law challenges dominant scholarship on global governance to listen to alternative accounts and to theorise both the silences and the actions. It seems timely to ask how these diverse sites of feminist knowledge - both temporally and geographically spread - might inform future feminist methodologies on international law via a plural feminist account.

We take two contemporary methodologies to explore the potential for new feminist approaches that develop plural feminisms and that seek to disrupt the acknowledged limitations of existing gender law reform within the international arena. As plural feminisms there are many more framings than those we examine here and we write of feminist methodologies that should not be regarded as absolute, closed or definitive, rather partial and interlocking with the multiple, plural feminist histories and futures that already exist. The first methodology examines historiographies within feminist approaches, as a method of relevance to international legal methodologies. Through the development of contemporary international legal histories with a specifically feminist tenement and the development of feminist histories based on archive work within the space of international law we explore the space of a postcolonial feminist account of international legal and feminist archives. Second, we draw in the turn to peace as central motif within feminist writing on international law as setting the framework for feminist methodologies that need not be constrained by dominant Western or dominant US accounts of feminism or by the liberal legal expectations of existing legal structures and institutions.

\section{International Legal Histories and Feminist Historiographies}


In this section, we argue that feminist historiographies are a useful methodological tool to investigate the past and present of international law, supplementing and expanding existing postcolonial and transnational feminist approaches. ${ }^{26}$ This can be in terms of a feminist critique of disciplinary subjects and objects or in terms of the limits of law reform as satisfactory mechanisms to achieve social change. In line with feminist scholarship that has long recognised the tension between inclusion and transformation within the existing disciplinary boundaries, ${ }^{27} \mathrm{a}$ feminist approach to international legal history develops with two aims. First, to retrieve voices and experiences that have been overlooked in mainstream accounts of the discipline in order to fill the gaps in historical records and archive. We regard this as a space to invoke and apply intersectional feminist accounts that need not centre gender but rather pivot on gender's intersection with other vectors of power. As such, we approach gender as an identity and a symbolic ordering device that interlocks with constructions of race, ethnicity, class, age, ableism and religious assumptions within dominant power structures and institutions. Second, to theorise those gaps in order to develop new perspectives and knowledge that might lead to thinking about the relation between the law and the past differently. ${ }^{28}$

Scholarly interventions by feminist historians of women, gender and international law have often focused on inclusion, adding the voices and experiences of those who have been structurally marginalised by disciplinary canons. Excellent work has been done, for example, in writing the histories of international women's organisations: this approach takes the shape of a 'history from below' that considers feminism as a social movement, primarily deriving from the experience of struggle against dominant power relations. ${ }^{29}$ In other cases, historians of women and international relations have produced scholarship that threads women into the dominant histories of international diplomatic spaces and 'high politics' ${ }^{30}$ Other scholars have contributed to the

\footnotetext{
${ }^{26}$ Kapur, above note 4; Nesiah, above note 17.

${ }^{27}$ Nicola Lacey, Feminist Legal Theory and the Rights of Women, in Karen Knop, Gender and Human Rights, (Oxford University Press, 2004); Maria Drakopolou, Feminism and Consent: a Methodological Enquiry in Rosemary Hunter R and Sharon Cowan (eds), Choice and Consent: Feminist Engagements with Law and Subjectivity, (Routledge Cavendish London, 2007).

${ }^{28}$ Felice Batlan, Engendering Legal History, Law and Social Enquiry, Vol 30 (4) 2007.

${ }^{29}$ Leila J Rupp,Worlds of Women: the Making of an International Women's Movement (Princeton University Press, 1998); Marie Sandell M, the Rise of Women Transnational Activism: Identity and Sisterhood between the World Wars (IB Tauris, 2005).

${ }^{30}$ Glenda Sluga and Caroline James (eds), Women, Diplomacy and International Politics since 1500 (Routledge, 2016); Glenda Sluga, Women, Feminism and Twentieth-Century Internationalisms in Glenda Sluga and Patricia Clavin (eds), Internationalisms: a Twentieh-Century History (Cambridge University Press, 2017).
} 
history of women by increasing the visibility of women's knowledge production, and by tackling the absence of women from disciplinary canons from an intellectual political perspective, setting up new research agendas and thus addressing the complexity, the diversity and the marginalisation of women in the history of international thought. ${ }^{31}$ A different set of international legal scholarship laments the historical marginalisation of women experiences and, with a specific focus on armed conflicts, undertakes the task of creating legal arguments that could allow accountability for human rights violations of women in international fora and contexts. Knop's study of women's voting rights in the post-1919 plebiscites and the recognition of women's voices in the Trusteeship territories under the UN Charter, and Charlesworth's reference to the legal activism of International Council of Women focused on the inclusion of women's rights in the Covenant of the League of Nations, are just two examples of this type of literature. $^{32}$

Yet few works address the relation between foundational theories and practices of international law and institutions to centre the potentialities or limits of either gender legal reform or feminist transnationalism(s). In the field of legal history, Genovese writes on writing legal histories that focus on feminism as a category of historical analysis, rearticulating the relation between law, history and feminism in opposition to feminist history writing, that is, a shift beyond an excavation of the absence of women in mainstream history. ${ }^{33}$ Although Genovese reflects on the rich feminist tradition that looks at legal developments through gender histories, she laments the few epistemic engagements that shed light on feminist developments through law. ${ }^{34}$ In other words, the question is not how feminists use law as a political means or strategy for empowerment and/or reform, but rather how concepts within international law and feminism function as historical constructions in and of themselves, avoiding the teleological discourses of progress and failure. In fact, the risk of identifying feminism and gender law reform as a field of enquiry, argues Genovese, is to interpret it in terms of success or failure, or in other words to

\footnotetext{
${ }^{31}$ Patricia Owens, Women and the History of International Thought, 62 International Studies Quaterly (2018), 467481.

${ }^{32}$ Karen Knop, Diversity and Self-determination in International Law (Cambridge 2002); Hilary Charlesworth, Feminist Methods in International Law, (2) American Journal of International Law, 93 (1999), 379-394

${ }^{33}$ Anne Genovese, 'How to Write Feminist Legal History: Some Notes on Genealogical Method, Family Law, and the Politics of the Present' in Diane Kirkby (ed), Past Law, Present Histories, (ANU Press, 2012) 142

${ }^{34}$ A Genovese, Writing the past as politics: some reflections on historiography and Margaret Hnderson, Lilith. 17, 2011; Marie Drakopolou, Feminist Encounters with Legal Philosophy (Routledge, 2014).
} 
interpret feminism as 'a battle that has been won or a revolution that promised a lot and delivered little' ${ }^{35}$ Inspired by this feminist legal critique, we take a transformative perspective to look at feminist approaches to the history of international law which consider the appreciation of a plurality of 'voices' in the archives as a central methodological commitment, ${ }^{36}$ shifting the focus of the analysis from the marginalised subjects in the historical accounts of the discipline to the gendering of the discipline of international law itself. This requires questioning how race, gender, class and sexuality have been central in constructing foundational concepts within international law, scripting intersectionality as a mechanism for engaging legal histories in a way that delves into the intersections of colonialism, gender and legal history and questions linear teleologies or genealogies of gender and international law. Simultaneously, this approach imposes a reflection on how to epistemologically, ontologically and methodologically conceive the archive as a space of knowledge production and governmentality, ${ }^{37}$ in order to highlight the assumptions of the discipline itself and to embed the possibility of change at a deep structural level.

An active engagement with history making and archive keeping has historically been at the core of transnational feminist projects, often prompted by feminist recognition of the gendered and unbalanced power relations in accessing and producing knowledge in male-dominated social realms. Feminists' struggles for inclusion in the public international (legal) arena have often gone parallel to the effort of establishing women's and feminist archives, as a way to ground legitimacy to women's voices and experiences in the future. For example, early twentieth century feminist activism in international organisations produced a little acknowledged story of the 1915 International Congress of Women at The Hague. ${ }^{38}$ Rosa Manus, Dutch feminist pacifist and suffragist, co-established the first (in Europe) International Archive for the Women's Movement (IAW) in Amsterdam in 1935, precisely with the aim of promoting the knowledge of

\footnotetext{
${ }^{35}$ Anne Genovese, How to Write Feminist Legal History: Some Notes on Genealogical Method, Family Law, and the Politics of the Present in Diane Kirkby, Past Law, Present Historie (ANU Press, 2012) 140.

${ }^{36}$ Thinking about 'listening' in law and beyond, comes from reading Dianne Otto, Beyond Legal Justice: Some Personal Reflections on People's Tribunals, Listening and Responsibility, 5London Review of International Law 2 (2017) 225-249; and Gina Heathcote, Feminist Dialogues on International Law. Successes, Tensions, Futures, (Hart, Oxford 2018).

${ }^{37}$ Ibid.; Wendy Brown, Politics out of History (Princeton University Press, 2001).

${ }^{38}$ Freya Baetens, 'International Congress of Women (1915)', in Rudiger Wolfrum (ed), Max Planck Encyclopedia of Public International Law (Oxford 2010)
} 
the international women's movement and in order for the archive to be the centre for collecting and preserving the 'cultural heritage' of women. ${ }^{39}$ Yet, we argue, gendering international legal histories requires the analysis of the archive as a symbolic space complicit in reproducing the inequalities at the core of both feminist politics and the international legal discipline, questioning not only what counts as 'legal evidence' but what counts as 'feminism'. That is Manus' work must be understood as a powerful record of women's engagements with international law and a partial account of the international, given the capturing of elite Western women's engagements in the archive itself.

Stoler provides path-breaking analysis of how the colonial, racialised and gendered treatment of sexuality has been central for Eurocentric historiographies of the empire. ${ }^{40}$ Similarly, Burton's analysis of imperial governance and on how archival forms rely on racialised epistemologies and ontologies that informs archival materials and knowledge has been central in many disciplines, not least in theories of historiography, as it compels scholars to think of writing histories not only in terms of what or where evidences and archives are located, but rather how they are historically constituted and what are the conditions of their existence. ${ }^{41}$ Moreover, feminist scholar Hartman tackles the deafening silences of the colonial archives on the Trans-Atlantic slave trade, and the way it affects what she calls the after-life of slavery: racialised dispossession, violence, and lack of opportunities are still at the very core of the reality in which international law operates. In filling the gaps of the archive through literary imagination, Hartman writes with consciousness of the tensions between literature and history, and the risk of offering revisionist account of the historical, colonial and legal experience. In fact, she refrains from indulging in literary creation and fiction, but rather interrogates how we can generate different sets of histories through

\footnotetext{
${ }^{39}$ Also known as 'international information Centre and archives for the women's movement or ATRIA Institute on Gender Equality and Women History. Myriam Everard and Francisca de Haan (eds) Rosa Manus (1881-1942): The International Life and Legacy of a Jewish Dutch Feminist (Brill 2018).

${ }^{40}$ Anne L Stoler, Along the Archival Grain Epistemic Anxieties and Colonial Common Sense (Princeton University Press, 2008). Ibid., Race and the Education of Desire: Foucault History of Sexuality and the Colonial Order of Things, (Duke University Press, 1995).

${ }^{41}$ Antoniette Burton A, Empire in Question: Reading, Writing, and Teaching British Imperialism (Duke University Press, 2011).
} 
listening to the silences of the archive, so that the historical value of unconventional sources is recuperated in order to fill the gaps of a (feminist) transnational history. ${ }^{42}$

A focus on artefacts and objects of international law has also become a signifier of a new materialist perspective that looks at how international law operates on the micro level, on the everyday, and on the local scale as well within the global scale. ${ }^{43}$ Considering how the history of international law has often relied on teleological narratives of modernity, progress, well-being and civilisation, Chiam, Esclava et al. ask how to write histories of international law that question the ways in which materials are chosen and organised as an assemblage of sources, and the 'order of things' realised through writing histories of international law that relies on conventional sources. ${ }^{44}$ International treaties, diplomatic papers and doctrinal sources seem to offer little scope when it comes to challenging pre-constituted assumptions of the international, colonial and even feminist governmentality and colonial governance, nor are they helpful to develop critical feminist accounts of international law in ways that 'challenge the enabling conditions and distributive implication of international law in ways that are intellectually versatile and politically relevant'. ${ }^{45}$ Scholarship on international legal histories draw in different sets of textual sources and material artefacts, from personal diaries and biographies to oral histories or art ephemera and artefacts, normally relegated into the realm of the non-legal, to then be reconsidered by different scholars not only as primary source materials, as evidences, but also as a way to redraw the boundaries of what constitutes the field, the archive of international law. ${ }^{46}$ A combined appreciation of the development of legal history as method in international law and of the contemporary feminist understanding of the intersectional silences of the archive inform our approach to plural feminisms.

\footnotetext{
${ }^{42}$ Saidiya Hartman Lose Your Mother: A Journey Along the Atlantic Slave Route (Macmillan 2008);, Ibid., 'Venus in Two Acts' (2008) 12(2) Small Axe: A Caribbean Journal of Criticism 1; also see Campt, T, Listening to Images (Duke University Press: 2017)

${ }^{43}$ Jessie Hohmann J and Daniel Joyce, International Law's Objects, Oxford University Press, 2018; Luis Eslava L, Local Space, Global Life: The Everyday Life of International Law and Development (Cambridge University Press 2014).

${ }^{44}$ Madaleine Chiam, Luis Eslava, Genevieve R Painter, Rose Parfitt, and Charlotte Peevers (eds). History, Anthropology and the Archive of International Law. London Review of International Law 5 (2017)

45 Vasuki Nesiah, Priorities of Feminist Legal Research: A sketch, a draft agenda, a hint of an outline..., 1 feminists@law(2011)3

${ }^{46}$ Chiam et al (above 42)
} 
Through juxtaposing the multiplicity of archival sources and voices, by self-reflectively exploring the diverse archival sites of feminist legal activism and spaces of international knowledge production, feminist historiographies can offer fruitful methodological tools to critically question present feminist and critical approaches to international law, examining the construction of identity that emerges from within and the normative claims imbued therein. In this sense, through exploring the intersectional and postcolonial dimensions of the development of a turn to historiography within feminist approaches to international law we aim to contribute to write alternative accounts of international law, gender and empire in the present. In other words, by posing broader questions of hegemony and governmentality, by engaging with racialised and gendered biases in the process of international law-making, a feminist historical lens on international law can advance scholarly enquiries on the imperial roots of international law and on the implications of structural biases and hierarchies in both international knowledge production and in current developments of gender and international law.

\section{Peace as Guiding Principle}

In this section we wish to highlight the role of peace as a guiding principle in the design and configurations of feminist methodologies. This approach builds on the previous section, recognizing the long history of feminist engagement with the structures of international law and the contemporary recognition of that history as shaping the contours of both gender law reform and feminist methodologies. We begin with identification of the history of feminist peace activism, its successes and limitations as well as the persistent failures of international legal actors - scholars and jurists - to remember, identify or take note of the interventions of feminist actors. However, at the same time we highlight the limited feminist knowledge that filters into mainstream international spaces, whether institutional, legal tools or academic, and the dominance of narrow versions of US and European feminisms that are represented within gender law reforms. We shape the focus around peace, at once identifying feminist methodologies as deeply concerned with the central focus of twentieth century international law while simultaneously articulating a project for peace that does not fall into the persistent trap of speaking about armed conflict as a means to understand peace. Within the focus on peace we centre the life of Jane Addams which, we argue, holds many of the tensions we wish to illuminate in this chapter, including the silence of mainstream international legal knowledge (and 
histories) on the contributions of feminist thinkers and actors, the transnational nature of feminist knowledge, the tendency of mainstream feminist accounts to dislodge feminist diversity and the linkage of an international peace project with the politics of everyday.

The early twentieth century and the turn to codification as a mechanism for peace within international law saw many women's suffrage campaigners engaged and participating in key debates and events within the international realm. However, the historical record seems to have recorded the acts of great men, while ignoring the significant contributions of women, such that the political writings of women are not part of the 'story' of international law. When a woman was also avowedly feminist in her political discourse the silence in international legal histories further contributes to the forgetting of the long trajectories of feminist knowledge and, as we argue in this chapter, the association of feminist and peace projects within international law.

Given the acknowledged role of 'legal publicists' in the formation of international jurisprudence there is significant value in tracing the acts and the written submissions of feminists who were active in the shaping of the League of Nations, who instrumentalised the League as a space of civic engagement and who articulated an understanding of peace that has considerable resonance with the contemporary concerns of international lawyers. Our goal in this section is thus twofold: one, to identify the legal contributions - that is, the contributions to knowledge - of feminist actors in the period of the League and immediately prior as a means to understand contemporary international law and, two, to identify the methodology of looking into the archive as central to contemporary feminist methodologies - an approach that also draws out attention to the feminist method of linking the everyday to the international. We argue for a conscious bridging of wider feminist and gender scholarship on the archive and contemporary international legal methodologies that articulate legal histories and contemplation of objects as method. We use Jane Addam's and Ellen Gates Starr's settlement project, Hull House, as object to inform the trajectory of knowledge. ${ }^{47}$

\footnotetext{
${ }^{47}$ Jane Addams, Twenty Years at Hull-House: With Autobiographical Notes, (MacMillan, New York: 1910) available online at: http://digital.library.upenn.edu/women/addams/hullhouse/hullhouse.html (accessed August 2020)
} 
The history of social work is often articulated as tied up in the history of Hull House and personified in the life of Jane Addams. Likewise, the history of the Women's International League for Peace and Freedom (WILPF) - and sometimes future - is also told, and personified, through the life of Jane Addams. ${ }^{48}$ Addams' acts, such as the founding of Hull House, or the founding of WILPF, become her contribution. Her Nobel Peace Prize is told as recognition of her acts. There remains, however, a silence of mainstream international legal knowledge (and histories) on the contributions of feminist thinkers and actors as authors, as thinkers, as writers, as contributors to legal knowledge. This strange gendering of knowledge, where men are understood for their intellectual contribution, for the shaping of knowledge, is worthy of further attention.

How is it that Hull House receives equal attention to that given to Jane Addams and that her writing so little attention, or that her contribution to social work, as a field of knowledge, is understood through an act (founding Hull House, travelling to England and drawing from the model established at Toynbee Hall) just as the act of founding WILPF is understood as the contribution of Addams - not the ideas beneath either founding act or the nexus between the two? Our first claim is thus to challenge the gendered forgetting of knowledge, not only for the failure of international law as a discipline to see and incorporate the histories of feminist activism in its development but also the gendered remembering that does occur so that the substance of women's lives becomes markers for their exceptionality while permitting a continued forgetting of feminist thinking and praxis.

To think differently in this chapter, we consider the various ways different types of knowledge are forgotten and yet essential to feminist methodologies. Thus our second claim is to elevate and consider transnational translations of knowledge, thus drawing in Knop's account of the transnational, ${ }^{49}$ we suggest Addam's transplanting of the Toynbee House model into the US context as a motif for how transnational feminist accounts, from suffrage, to security issues, to violence against women and the trajectories of intersectionality, move sideways, are ever reimagined and yet traceable in a horizontal fashion. This is a feature of transnational feminist

\footnotetext{
${ }^{48}$ Felicity Ruby, 'Security Council 1325: a Tool for Conflict Resolution?' in Gina Heathcote and Dianne Otto (eds), Rethinking Peacekeeping, Gender Equality and Collective Security (Palgrave 2014) 173

${ }^{49}$ Knop, above note 10
} 
organising that is central to the flows of knowledge and its reproduction in new contexts that responds to and adapts to different legal, cultural and political realities (amongst others) and yet is a feature that, like the feminist knowledge that international legal histories dismiss as stories of women/ feminist lives, is not captured in the histories and presents of knowledge structures. This is, in effect, a gendering of what is valued and how knowledge is understood to persist and travel. Absent the hierarchal political and legal ordering of Western histories of democracy and liberalisms, feminist knowledge is reimagined as not knowledge, as ahistorical and as often 'owned' or originating in international institutions. The Security Council resolutions on women, peace and security are a good example of precisely this type of framing. Although feminist actors trace and know the history of the resolutions as travelling from Hull House and the work of Jane Addams and her contemporaries, as equally as the many feminist acts and knowledge frames in conflict and post-conflicts globally, the pinpointing of Security Resolution 1325 as springing forth in 2000 re-purposes the longer transnational femnist history as secondary to the 'moment' the international community understood the importance of women's lives and contributions to peace and security. The Security Council then deploys a range of interventions and policies into / onto post conflict and conflict states that silence the existing frames and applications of understandings of gender, of conflict, and of peace within feminist networks.

Third, drawing in Addams' work on peace within the League of Nations addresses not gendered subjects but feminist peace. This discloses a feminist project for peace that does not fixate on women's lives but understands a feminist appraisal of peace as the universal / international trajectory of feminist thinking. The tendency of mainstream feminist accounts to dislodge feminist diversity is both historical and current. Addams' work, which centred on the living of an alternative type of peace that welcomed refugees, that transformed communities through attention to the least well off and that ignored the conventions of heteronormative respectability, is a fascinating record of feminist praxis that has otherwise been subsumed into a trajectory of women at the League, and then the United Nations, without a sufficient account of the methods and thinking behind her work. That Addams produced an oeuvre of work that records and centres this politics is not generally regarded as a matter of relevance to international lawyers. That is, Addams is a gendered subject but not a thinker on feminist peace that might inform international law today. As a thinker on feminist peace she offers a blueprint for organising the global order 
differently, with attention to those not recognised by the practices of statehood and nation, with attention to the relationship between poverty and insecurity and with a livelihood that rejects the role of heteronormativity as a means to order dominant world frames. At the same time, we are aware that in framing Addams' contribution to peace studies, to social work and to international law functions as a further silencing of those transnational feminist acts, writings and activisms not in English, not awarded a Nobel Peace Prize and not in the United States. Plural feminist methodologies require both a reexamination of the knowledge projects of those sat within international spaces but gendered female, and thus excluded from the canon, and the voices not held and not centred in Manus' or Addams' engagements with the League, and beyond.

\section{Feminist Methodologies}

To conclude, we wish to return to the notion of plural feminisms as the key to future feminist methodologies. We have highlighted feminist historiographies as one method, that we argue, builds contemporary gender methodologies, critical legal histories and feminist peace studies in dialogue with mainstream feminist knowledge within international law. Implicit within our approach is the incorporation of intersectional feminist methodologies and an attentiveness to the concerns and contributions of post-colonial feminisms. We regard intersectionality and postcolonial feminisms as providing the starting point for plural feminist engagements with international law. We recognise feminist knowledge on international law that circulates in the mainstream, in policy and institutional spaces and in transnational feminist activisms, such that the relationship between feminist approaches as they emerged within international legal writing in the 1990s, and the subsequent gender law reforms, are of considerable importance to our argument which examines how gender law reform has developed in a fragmented fashion and in a manner constrained by the structures and biases of the institutions they emerge within. Global constraints, such as the rise of expertise and the reliance on indicators, that create a seemingly depoliticized international space further reduces the effectiveness of gender law reforms. As such, using postcolonial feminist methodologies and accounts of intersectionality becomes necessary to challenge the 'thin' construction of gender that emerges in much law reform. This is the reduction of gender to women and the focus on gender in isolation from other vectors of power and privilege, including race, ethnicity, religion, sexuality and ableism, such that gender law reform risks the perpetuation of empire and histories of imperialism within new modes of 
gender law reform or the production of neoliberal feminisms that are disconnected from feminist political agendas and histories.

We have used this chapter to elaborate the contours of plural feminisms that draw in feminist historiographies and critical international legal histories to make three methodological claims. First, the need for centering the writing of transnational feminist histories into both international legal and feminist legal knowledge production. Second, attention to the need to question how histories, including legal histories, reproduce knowledge about gender, fixing categories of inclusion and exclusions, and engendering structural bias beyond gender. Third, through drawing in feminist and gender theories on history, the archive and artifacts, we argue for the queering and disruption of gendered objects that build standard histories of gender, law and the international law. Within this methodological account we place reflections on Hull House and the scholarship of Jane Addams, immediately encountering the contradictions about the scope and focus of feminist histories of international law - both local and international, centred on peace, economies of power and race, threaded through with both privilege and untold stories of sexuality. We raise Jane Addams' building of Hull House as a community to offer questions, to centre feminist histories of both feminist lives and feminist knowledge and to explore further the continuum of violence and its intertwined relationship with the quest for feminist peace or plural feminisms. Plural feminisms and legal pluralisms shift beyond mainstream feminist knowledge frames within international law, are attentive to plural subjectivities, and actively acknowledge the histories of empire: these are feminist methodologies for the twenty-first century. 